
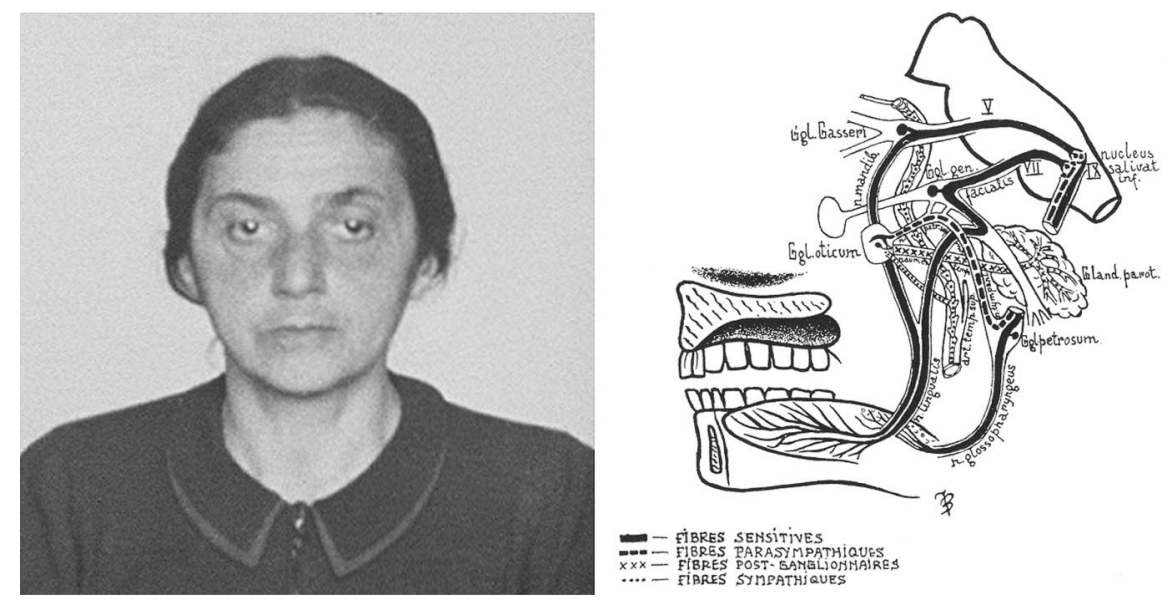

Figure. (Left) Lucja Frey (1889 to 1942[?]). This photograph is from a document Frey completed in September 1941, which was used by German authorities to issue work permits in occupied Poland. (With permission of the U.S. Holocaust Memorial Museum). (Right) Figure used to illustrate Frey's description of the auriculotemporal syndrome (Frey L. Le syndrome du nerf auriculo-temporal. Rev Neurol (Paris) 1923;II:97-104. With permission, Masson, Paris, 1923).

\section{VIDEo Gustatory sweating: Frey syndrome}

Stephen G. Reich, MD; and Stephen E. Grill, MD, PhD, Baltimore, $M D$

One year after resection of a parotid neoplasm, a 44-year-old man developed sweating over the left side of the face while eating (see video). He had to continuously dab his face with a cloth during a meal. He has been treated successfully with botulinum toxin. Gustatory sweating, known as Frey syndrome, ${ }^{1}$ results from misdirected regeneration of parasympathetic fibers normally innervating salivary glands onto sympathetic receptors innervating sweat glands following injury to the auriculotemporal nerve. As a result, stimuli that cause salivation, such as eating, the aroma of food, or even the thought of food, simultaneously cause pathologic sweating in the preauricular area on the side of injury to the facial nerve. Local injection of botulinum toxin to the region of involved sweat glands is an effective treatment for gustatory sweating as it inhibits the presynaptic release of acetylcholine, the neurotransmitter that innervates sweat glands. ${ }^{2,3}$

Disclosure: The authors report no conflicts of interest.

Address correspondence and reprint requests to Dr. S.G. Reich, Neurology, University of Maryland School of Medicine, N4W46, 22 South Greene Street, Baltimore, MD 21201; e-mail: sreich@som.umaryland.edu
The Polish neurologist Lucja Frey was not the first to describe gustatory sweating but she is credited with its first complete description (figure). ${ }^{1}$ Frey received her medical diploma from the University of Warsaw in 1921 and subsequently worked in the neurologic clinic, publishing 43 articles between 1923 and $1928 .{ }^{4}$ She was described as "extraordinarily modest, quiet and as hard working as an ant." ${ }^{\prime}$ In 1928 she returned to her hometown of Lwow as deputy senior consultant at the Jewish Hospital. After German occupation, she practiced in the Lwow ghetto. Details about her death are not available, but she was a victim of the Holocaust, likely killed in 1942 along with 400 other members of the medical staff, or shortly thereafter, cutting short her promising career. ${ }^{4}$

\section{Acknowledgment}

The authors thank Dr. Bernd Remler for help with translation.

1. Dunbar EM, Singer TW, Singer K, Knight H, Lanska D, Okun MS. Understanding gustatory sweating. What have we learned from Lucja Frey and her predecessors? Clin Auton Res 2002;12:179-184.

2. Kreyden OP, Scheidegger EP. Anatomy of the sweat glands, pharmacology of botulinum toxin, and distinctive syndromes associated with hyperhydrosis.Clin Dermatol 2004;22:40-44.

3. Naumann M, Jost W.Botulinum toxin treatment of secretory disorders. Mov Disord 2004;19(suppl 8):S137-S141.

4. Moltrecht M, Michel O.The woman behind Frey's syndrome: The tragic life of Lucja Frey. Laryngoscope 2004;114:2205-2209. 


\title{
Neurology
}

\author{
Gustatory sweating: Frey syndrome \\ Stephen G. Reich and Stephen E. Grill \\ Neurology 2005;65;E24 \\ DOI 10.1212/01.wnl.0000182298.85958.46
}

This information is current as of December 12, 2005

\section{Updated Information \& Services}

Supplementary Material

\section{References}

Subspecialty Collections

Permissions \& Licensing

\section{Reprints}

including high resolution figures, can be found at: http://n.neurology.org/content/65/11/E24.full

Supplementary material can be found at: http://n.neurology.org/content/suppl/2005/12/05/65.11.E24.DC1 http://n.neurology.org/content/suppl/2005/12/05/65.11.E24.DC2

This article cites 3 articles, 0 of which you can access for free at: http://n.neurology.org/content/65/11/E24.full\#ref-list-1

This article, along with others on similar topics, appears in the following collection(s):

Autonomic diseases

http://n.neurology.org/cgi/collection/autonomic_diseases Cranial neuropathy http://n.neurology.org/cgi/collection/cranial_neuropathy

Information about reproducing this article in parts (figures,tables) or in its entirety can be found online at:

http://www.neurology.org/about/about_the_journal\#permissions

Information about ordering reprints can be found online: http://n.neurology.org/subscribers/advertise

Neurology ${ }^{\circledR}$ is the official journal of the American Academy of Neurology. Published continuously since 1951, it is now a weekly with 48 issues per year. Copyright. All rights reserved. Print ISSN: 0028-3878. Online ISSN: 1526-632X.

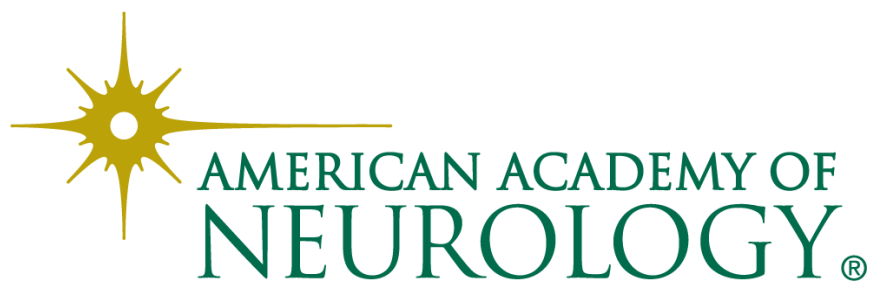

